\title{
A rare initial clinical presentation of pheochromocytoma
}

\author{
Hania Burgan, Julien Celi
}

Urgences, Hôpitaux universitaires de Genève, Genève, Switzerland

Correspondence to Dr Hania Burgan, haniaburgan@bluewin.ch

Accepted 11 May 2019

\section{DESCRIPTION}

A 44-year-old man with treated hypertension presented to the emergency department after experiencing acute right flank pain. He described measuring hypertension, followed by malaise sensation, sweating and rapidly progressive right flank pain. On arrival, the patient was conscious, normotensive, with sinus tachycardia, alternating with supraventricular tachycardia and non-sustained ventricular tachycardia. He was diaphoretic with pale clammy skin and cold extremities. Laboratory studies showed lactic acidosis, hyperglycaemia, with a haemoglobin drop (from 139 to $110 \mathrm{~g} / \mathrm{L}$ within an hour). A focused assessment with sonography for trauma (FAST) ultrasound showed a large hypoechogenic right pararenal mass (figure 1). An abdominal CT scan showed an acute haemorrhage originating from a right suprarenal hypervascularised mass compatible with a ruptured pheochromocytoma (figure 2). Blood pressure became extremely labile with severe hypertension and moments of hypotension.

The patient was admitted to the intensive care unit and treated with aggressive antihypertensive therapy. He developed multiple organ failure with severe stress cardiomyopathy (30\% left ventricular ejection fraction) and type 2 Non-ST-Elevation Myocardial Infarction, acute renal insufficiency, low hepatic dysfunction and abdominal compartment syndrome. Plasma normetanephrines and metanephrines came back highly positive. After stabilisation, right adrenalectomy was performed. Histopathology of the right suprarenal mass confirmed an $8 \mathrm{~cm}$ ruptured pheochromocytoma, with important intratumorous haemorrhage. The clinical outcome thereafter was favourable, with normalisation of left ventricular ejection fraction.

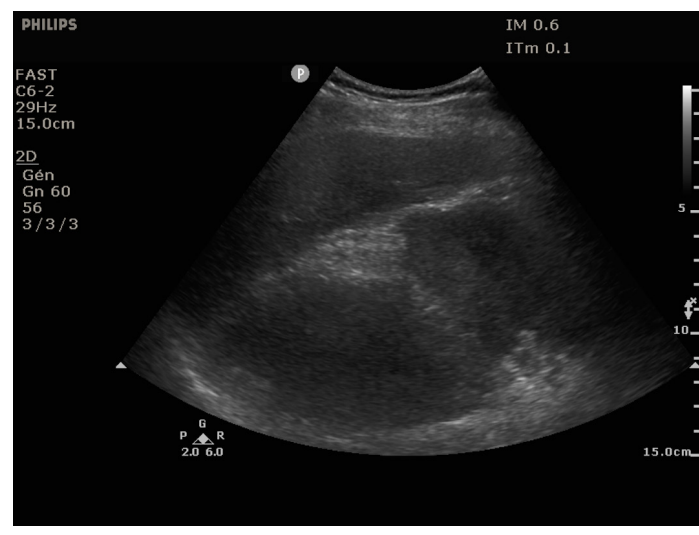

Figure 1 Hypoechogenic mass on focused assessment with sonography for trauma (FAST) ultrasound.

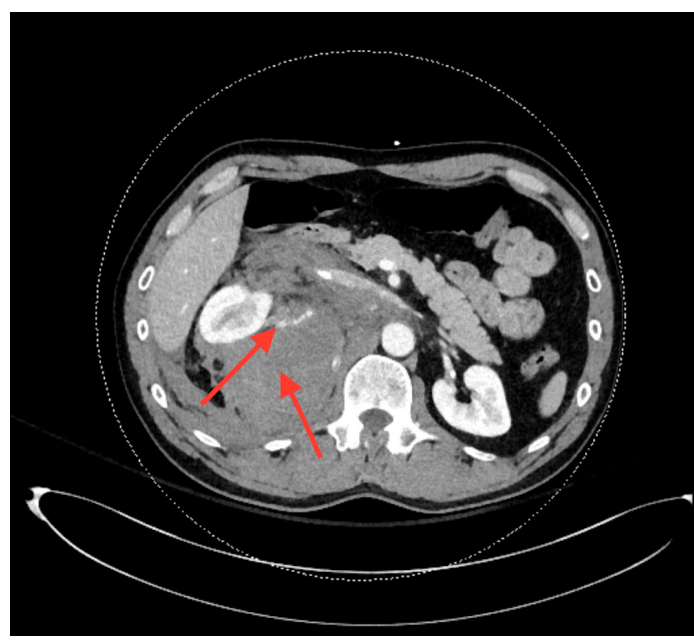

Figure 2 Active low intensity haemorrhage (left arrow), perirenal and retroperitoneal haematoma (right arrow).

In this young patient with a large tumour, a germline mutation in one of the genes responsible for hereditary pheochromocytomas and/or paragangliomas was searched for. The analysis included variants in 21 different genes and came back negative.

Pheochromocytoma is a rare disease with variable clinical presentation, affecting less than $0.2 \%$ of patients suffering from hypertension. ${ }^{1}$ Pheochromocytoma rupture with haemorrhage is a very rare initial clinical presentation of pheochromocytoma, with less than 60 cases described in the literature. If not rapidly recognised, it can result in the patient's death, most commonly from hypovolemia due to haemorrhage, heart failure from catecholamine cardiomyopathy or respiratory disorder from pulmonary oedema. ${ }^{23}$ Initial correct diagnosis is made in only $30 \%$ of cases. ${ }^{2}$ Most cases are diagnosed with CT. In this case, we show the use of FAST ultrasound in locating the pararenal

\section{Learning points}

Pheochromocytoma is a very rare disease with an extremely variable clinical presentation.

- Pheochromocytoma rupture is a rare clinical presentation, but can be life-threatening if not rapidly recognised, due to hypovolemia, catecholamine cardiomyopathy or respiratory disorder.

- Focused assessment with sonography for trauma (FAST) ultrasound can be used in the emergency setting, although CT scan is the preferred imaging modality for diagnosis. 
haemorrhage, which guided ordering emergent CT, confirming the rare diagnosis.

Contributors $\mathrm{HB}$ and JC provided care to the patient. HB wrote the initial version of the report. JC critically reviewed and approved the final version of the manuscript.

Funding The authors have not declared a specific grant for this research from any funding agency in the public, commercial or not-for-profit sectors.

Competing interests None declared.

Patient consent for publication Obtained.
Provenance and peer review Not commissioned; externally peer reviewed.

\section{REFERENCES}

1 Stein PP, Black HR. A simplified diagnostic approach to pheochromocytoma. A review of the literature and report of one institution's experience. Medicine 1991:70:46-66.

2 Kobayashi T, Iwai A, Takahashi R, et al. Spontaneous rupture of adrenal pheochromocytoma: review and analysis of prognostic factors. I Surg Oncol 2005;90:31-5.

3 Lenders JWM, Eisenhofer G, Mannelli M, et al. Phaeochromocytoma. The Lancet 2005;366:665-75.

Copyright 2019 BMJ Publishing Group. All rights reserved. For permission to reuse any of this content visit

https://www.bmj.com/company/products-services/rights-and-licensing/permissions/

BMJ Case Report Fellows may re-use this article for personal use and teaching without any further permission.

Become a Fellow of BMJ Case Reports today and you can:

- Submit as many cases as you like

- Enjoy fast sympathetic peer review and rapid publication of accepted articles

- Access all the published articles

- Re-use any of the published material for personal use and teaching without further permission

\section{Customer Service}

If you have any further queries about your subscription, please contact our customer services team on +44 (0) 2071111105 or via email at support@bmj.com.

Visit casereports.bmj.com for more articles like this and to become a Fellow 